\title{
Implementasi Pendidikan Kewirausahaan (Entrepreneurship) di Sekolah Dasar/Madrasah Ibtidaiyah
}

\author{
Muhamad Afandi \\ Universitas Islam Negeri Raden Fatah Palembang \\ muhammadafandi_uin@radenfatah.ac.id
}

\begin{abstract}
This study aims to discuss and see the evaluation of entrepreneurship education in elementary schools / madrasah ibtidaiyah. Elementary schools and madrasah ibtidaiyah that have implemented entrepreneurship education that can be used as references include: SD Entrepreneur Muslim Alif-A Piyungan Yogyakarta, SD IT Alam Harum Purbalingga, and MI Terpadu Qurrota A'yun Ponorogo. This research uses a qualitative approach. This type of research data is qualitative data and the data source is secondary data. While the data method used is library research (library research). Data analysis techniques through data reduction, data display, and withdrawal from the literature study conducted. Meanwhile, to check the validity of the data using triangulation of data sources. The results of this study explain that, the implementation of Entrepreneurship Education in elementary schools / madrasah ibtidaiyah can be carried out in three stages, namely: (1) The planning stage, including: formulation of program objectives, program vision and mission of entrepreneurship education, material which then incorporates educational values. entrepreneurship that will be developed in the Learning Implementation Plan; (2) Implementation stage, including: class, entrepreneurship, integrated with subjects, self-development activities, school culture; and (3) The evaluation phase, including entrepreneurial education activities based on entrepreneurial values that have been internalized and implemented in the behavior seen in the activities of students at school.
\end{abstract}

Keywords: Entrepreneurship, madrasah ibtidaiyah, education, elementary school

Abstrak: Penelitian ini bertujuan untuk membahas dan mengetahui implementasi pendidikan entrepreneurship di sekolah dasar/madrasah ibtidaiyah. Sekolah dasar dan madrasah ibtidaiyah yang telah mengimplementasikan pendidikan entrepreneurship yang dapat

AR-RIAYAH : Jurnal Pendidikan Dasar vol. 5, no. 1, 2021

IAIN Curup - Bengkulu l p ISSN 2580-362X; e ISSN 2580-3611

http://journal.iaincurup.ac.id/index.php/JPD

DOI: $10.29240 /$ jpd.v5i1. 2671 | p. 51-64 
dijadikan rujukan antara lain di SD Entrepreneur Muslim Alif-A Piyungan Yogyakarta, SD IT Alam Harum Purbalingga, dan MI Terpadu Qurrota A'yun Ponorogo. Penelitian ini menggunakan pendekatan kualitatif. Jenis data penelitian ini adalah data kualitatif dan sumber datanya berupa data skunder. Sedangkan metode pengumpulan data yang digunakan adalah penelitian kepustakaan (library research). Teknik analisis data melalui reduksi data, display data, dan penarikankesimpulan dari studi literatur yang dilakukan. Sedangkan untuk pengecekan keabsahan data menggunakan triangulasi sumber data. Hasil penelitian ini menjelaskan bahwa, implementasi Pendidikan Entrepreneurship di sekolah dasar/madrasah ibtidaiyah dapat dilaksanakan melalui tiga tahap, yaitu: (1) Tahap perencanaan, meliputi: perumusan tujuan program, visi dan misi program pendidikan entrepreneurship, menentukan materi pelajaran kemudian memasukkan nilai-nilai pendidikan entrepreneurship yang akan dikembangkan dalam Rencana Pelaksanaan Pembelajaran; (2) Tahap pelaksanaan, meliputi: kelas, mata pelajaran entrepreneurship, teritegrasi dengan mata pelajaran, kegiatan pengembangan diri, kultur sekolah; dan (3) Tahap evaluasi, meliputi kegiatan penilaian pendidikan entrepreneurship yang didasarkan pada nilai-nilai entrepreneurship yang telah terinternalisasi dan terimplementasi dalam perilaku yang terlihat pada aktivitas peserta didik di sekolah.

Kata Kunci: Entrepreneurship, kewirausahaan, madrasah ibtidaiyah, pendidikan, sekolah dasar

\section{PENDAHULUAN}

Pertumbuhan ekonomi Indonesia sebagai negara berkembang sangat dipengaruhi dari Produk Domestik Bruto (PDB) yang dihasilkan. Pada masa pandemi covid-19 ini, seluruh negara di dunia mengalami penurunan atau pelambatan pertumbuhan ekonomi. Indonesia sendiri mengalami pelambatan pertumbuhan ekonomi sebesar 2,97\% (year on year). Sedangkan pengangguran akibat Pemutusan Hubungan Kerja (PHK) sebesar 212.394 pekerja. Dari data tersebut dapat disimpulkan bahwa pelambatan pertumbuhan ekonomi telah berimplikasi terhadap peningkatan pengangguran di Indonesia. Peningkatan jumlah pengangguran ini pada akhirnya juga mengakibatkan defisit anggaran negara bertambah. Peningkatan defisit APBN Indonesia tahun 2020 sebesar $6,27 \%$ diukur dari PDB. ${ }^{1}$

${ }^{1}$ Siti Indiyani dan Budi Hartono, Analisis Pengangguran dan Pertumbuhan Ekonomi sebagai Akibat Pandemi Covid-19, Perspektif: Jurnal Ekonomi \& Manajemen Universitas Bina Sarana Informatika, Volume 18 Nomor 2, (2 September 2020), hlm. 201-208. https://ejournal.bsi.ac.id/ejurnal/index.php/perspektif/article/view/8581 
Berdasarkan hasil perhitungan Badan Pusat Statistik pada Februari 2018, ada 6,87 juta pengangguran. Dilihat dari tingkat pendidikannya, tingkat pengangguran terbuka (TPT) untuk Universitas sebesar 6,31\%, tingkat diploma I/II/III sebesar 7,92\%, Sekolah Menengah Kejuruan (SMK) tertinggi di antara tingkat pendidikan lainnya yaitu sebesar $8,92 \%$, lulusan SMA sebesar 7,19\%, SMP sebesar 5,18\% dan SD paling sedikit yaitu sebesar 2,67\%. Berdasarkan data terbaru yang dirilis di website Badan Pusat Statistik pada Agustus 2020 dapat diketahui bahwa:

1. Jumlah angkatan kerja pada Agustus 2020 sebanyak 138,22 juta orang, naik 2,36 juta orang dibanding Agustus 2019. Sejalan dengan kenaikan jumlah angkatan kerja, Tingkat Partisipasi Angkatan Kerja (TPAK) juga naik sebesar 0,24 persen poin.

2. Tingkat pengangguran terbuka (TPT) Agustus 2020 sebesar 7,07 persen, meningkat 1,84 persen poin dibandingkan dengan Agustus 2019.

3. Penduduk yang bekerja sebanyak 128,45 juta orang, turun sebanyak 0,31 juta orang dari Agustus 2019. Lapangan pekerjaan yang mengalami peningkatan persentase terbesar adalah Sektor Pertanian (2,23 persen poin). Sementara sektor yang mengalami penurunan terbesar yaitu Sektor Industri Pengolahan (1,30 persen poin).

4. Sebanyak 77,68 juta orang $(60,47$ persen) bekerja pada kegiatan informal, naik 4,59 persen poin dibanding Agustus 2019.

5. Dalam setahun terakhir, persentase pekerja setengah penganggur dan persentase pekerja paruh waktu naik masing-masing sebesar 3,77 persen poin dan 3,42 persen poin.

6. Terdapat 29,12 juta orang (14,28 persen) penduduk usia kerja yang terdampak Covid-19, terdiri dari pengangguran karena Covid-19 (2,56 juta orang), Bukan Angkatan Kerja (BAK) karena Covid-19 (0,76 juta orang), sementara tidak bekerja karena Covid-19 (1,77 juta orang), dan penduduk bekerja yang mengalami pengurangan jam kerja karena Covid-19 (24,03 juta orang). ${ }^{3}$

Pertumbuhan ekonomi dan tingkat pengangguran menjadi salah satu indikator penting keberhasilan pembangunan suatu negara. Pertumbuhan ekonomi terjadi karena adanya pendapatan suatu negara secara nasional pada periode tertentu. Sedangkan pengangguran merupakan selisih angkatan kerja

\footnotetext{
${ }^{2}$ Nurma Midayanti, Keadaan Ketenagakerjaan Indonesia Februari 2018, Jakarta: Badan Pusat Statistik, 2018, hlm. 3

${ }^{3}$ Badan Pusat Statistik, [REVISI per 18/02/2021] Agustus 2020: Tingkat Pengangguran Terbuka (TPT) sebesar 7,07 persen, diakses pada: https://www.bps.go.id/pressrelease/2020/11/05/1673/agustus-2020--tingkat-pengangguranterbuka--tpt--sebesar-7-07-persen.html
} 
dengan serapan lapangan pekerjaan yang ada.4 Dengan demikian, pertumbuhan ekonomi suatu negara dipengaruhi juga dari produktivitas tenaga kerja yang terserap pada lapangan kerja. Hal ini terjadi karena tenaga kerja berkontribusi terhadap pendapatan negara.

Salah satu solusi yang dapat dilakukan adalah dengan menyiapkan generasi masa depan negara kita melalui pendidikan kewirausahaan atau entrepreneurship sejak pendidikan di tingkat dasar (SD/MI).Entrepreneurship merupakan kegiatan menciptakan dan mengelola suatu usaha baru. Unsur utama dari entrepreneurship adalah kreativitas dan inovasi. Kedua istilah tersebut berbeda, namun memiliki keterkaitan. Kreativitas adalah kemampuan seseorang dalam menghasilkan sesuatu yang baru dan berbeda. Sedangkan inovasi adalah produk atau jasa yang dihasilkan dari proses kreativitas tersebut. Ringkasnya, kreativitas adalah berpikir sesuatu yang baru (thinking new things), sedangkan inovasi adalah melakukan sesuatu yang baru (doing new things). Keduanya harus ada dalam entrepreneurship, karena menemukan ide-ide kreatif saja tidak cukup, harus diimplementasikan dalam usaha nyata dan inovatif.

Beberapa tahun terakhir, pemerintah Indonesia sedang giat mendorong berbagai kegiatan entrepreneurship. Diharapkan dengan adanya pendidikan entrepreneurship ini dapat menghasilkan lulusan yang lebih berkualitas, memiliki sikap optimis, kreatif, karismatik, stabil, energik, dinamis, serta berani mengambil risiko. ${ }^{6}$ Untuk mendukung kebijakan pemerintah tersebut, maka sudah menjadi kewajiban bagi lembaga pendidikan untuk membekali peserta didik dengan jiwa kewirausahaan melalui pendidikan entrepreneurship dari pendidikan tingkat dasar sampai dengan perguruan tinggi.

\section{A. Pendidikan Kewirausahaan}

Kata entrepreneur berasal dari bahasa Prancis, entre berarti "antara" dan prende berarti "mengambil". Kata ini pada dasarnya digunakan untuk menggambarkan orang-orang yang berani mengambil risiko dan memulai sesuatu yang baru. Selanjutnya, pengertian entrepreneurship diperluas hingga mencakup inovasi. Melalui inovasi munculah kebaharuan yang dapat berbentuk produk baru hingga sistem distribusi baru. Produk baru misalnya,tidak mesti terkait dengan teknologi canggih karena produk sederhana juga dapat menyajikan kebaharuan, contohnya rasa baru pada produk makanan.

\footnotetext{
${ }^{4}$ Indiyani dan Budi Hartono, Analisis Pengangguran dan Pertumbuhan..., Op. Cit. Hlm. 102

${ }^{5}$ Muchson, Buku Ajar Entrepreneurship (Kewirausahaan), Jakarta: Guepedia, 2017, hlm.32.

${ }^{6}$ Serian Wijatno, Entrepreneurship untuk Sekolah Dasar, Jakarta, Slemba Empat, 2012, hlm.1.

${ }^{7}$ Serian Wijatno, Pengantar Entrepreneurship, Jakarta: PT Gramedia Widiasarana Indonesia, 2009, hlm.2.
} 
Entrepreneurship atau kewirausahaan adalah usaha kreatif yang dibangun berdasarkan inovasi untuk menghasilkan sesuatu yang baru, memiliki nilai tambah, memberi manfaat, menciptakan lapangan kerja dan hasilnya berguna bagi orang lain. ${ }^{8}$ Entrepreneurship sebagai sebuah proses yang melibatkan usaha oleh pelaku (entrepreneur) yang berani menanggung resiko baik modal, waktu, atau komitmen karir dalam rangka menyediakan produktifitas tertentu berbasis pada manajemen yang baik. Entrepreneur harus dipahami tidak secara sempit terbatas pada konteks bisnis saja, tetapi juga dapat diterapkan pada bidang lainnya seperti pendidikan, kedokteran, arsitektur, pekerjaan sosial dan lain sebagainya. Selanjutnya, dalam konteks pendidikan entrepreneurship dapat dijelaskan sebagai pendidikan yang menerapkan prinsip-prinsip dan metodologi ke arah pembentukan jiwa entrepreneurship yaitu jiwa yang berani dan mampu menghadapi problem hidup dan kehidupan secara wajar, jiwa kreatif untuk mencari solusi dan mengetahui problem tersebut, jiwa mandiri dan tidak bergantung pada orang lain. ${ }^{9}$

\section{B. Nilai-Nilai Entrepreneurship}

Nilai-nilai yang dikembangkan dalam pendidikan kewirausahaan (entrepreneurship) adalah pengembangan nilai-nilai dari ciri-ciri seorang wirausaha (entrepreneur). Beberapa nilai-nilai kewirausahaan yang dianggap paling pokok dan sesuai dengan tingkat perkembangan peserta didik sebanyak 17 (tujuh belas) nilai, yaitu sebagai berikut: ${ }^{10}$

\begin{tabular}{cll}
\hline No & \multicolumn{1}{c}{ Nilai } & \multicolumn{1}{c}{ Deskripsi } \\
\hline 1 & Mandiri & $\begin{array}{l}\text { Tidak bergantung pada orang lain dalam mengambil } \\
\text { keputusan dan menjalankan tugas }\end{array}$ \\
\hline 2 & Kreatif & Menghasilkan sesuatu yang berbeda dari yang sudah ada \\
\hline 3 & $\begin{array}{l}\text { Berani } \\
\text { mengambil risiko }\end{array}$ & $\begin{array}{l}\text { Mampu untuk menghadapi dan menerima akibat atau } \\
\text { konsekuensi dari apa yang dilakukan }\end{array}$ \\
\hline 4 & $\begin{array}{l}\text { Berorientasi pada } \\
\text { tindakan }\end{array}$ & $\begin{array}{l}\text { Memiliki inisiatif untuk bertindak terhadap segala sesuatu } \\
\text { yang di perlukan }\end{array}$ \\
\hline 5 & Kepemimpinan & $\begin{array}{l}\text { Sikap terbuka terhdapa kritik dan saran, mampu } \\
\text { bekerjasama dan menjadi teladan }\end{array}$ \\
\hline 6 & Kerja keras & $\begin{array}{l}\text { Menyelesaikan tugas dan kewajiban dengan sungguh- } \\
\text { sungguh }\end{array}$ \\
\hline 7 & Jujur & $\begin{array}{l}\text { Perkataan dan tindakan sesuai dengan pekerjaan yang } \\
\text { dilakukan }\end{array}$ \\
\hline
\end{tabular}

${ }^{8}$ Edy Soeryanto Soegoto, Entrepreneurship Menjadi Pebisnis Ulung, Jakarta: PT Gramedia, 2009, hlm.26.

${ }^{9}$ Mohammad Darwis " Pendidikan Entrepreneurship dalam Pespektif Global" TARBIYATUNA [Online], Volume 9 Number 2 (15 August 2016), https://www.iaisyarifuddin.ac.id/ejournal/index.php/tarbiyatuna/article/view/240

${ }^{10}$ Tim Penulis Naskah Kewirausahaan, Pengembangan Pendidikan Kewirausahaan, Jakarta: Kementerian Pendidikan Nasional Badan Penelitian dan Pengembangan Pusat Kurikulum, 2011, hlm.10-11. 


\begin{tabular}{cll}
\hline 8 & Disiplin & Tertib, taat, dan patuh terhadap peraturan \\
\hline 9 & Inovatif & $\begin{array}{l}\text { Kreatif dalam memecahkan persoalan dan } \\
\text { mengembangkan hal-hal baru }\end{array}$ \\
\hline 10 & Tanggung jawab & Melaksanakan tugas dan kewajiban dalam pekerjaan \\
\hline 11 & Kerja sama & $\begin{array}{l}\text { Mampu menjalin hubungan dengan orang lain untuk } \\
\text { mencapai tujuan bersama }\end{array}$ \\
\hline 12 & $\begin{array}{l}\text { Pantang } \\
\text { menyerah (ulet) }\end{array}$ & $\begin{array}{l}\text { Tidak mudah putus asa dalam menghadapi masalah dan } \\
\text { selalu mencari alternatif solusi }\end{array}$ \\
\hline 13 & Komitmen & Kesepakatan terhadap diri sendiri atau orang lain \\
\hline 14 & Realistis & $\begin{array}{l}\text { Cara berpikir yang logis berdasarkan data dan fakta di } \\
\text { lapangan }\end{array}$ \\
\hline 15 & Rasa ingin tahu & $\begin{array}{l}\text { Sikap ingin mengetahui secara mendalam terhadap suatu } \\
\text { hal }\end{array}$ \\
\hline 16 & Komunikatif & $\begin{array}{l}\text { Mudah untuk membangun interaksi, kerjasama dan } \\
\text { berbicara dengan orang lain }\end{array}$ \\
\hline 17 & Motivasi kuat & $\begin{array}{l}\text { Memiliki semangat untuk melakukan sesuatu secara terus } \\
\text { menerus }\end{array}$ \\
\hline
\end{tabular}

Tabel 1.1: nilai-nilai Kewirausahaan

\section{Klasifikasi, Tahapan, dan Proses Entrepreneurship}

Menurut Ciputra, ada empat klasifikasi (kategori) dalam entrepreneurship, antara lain:

1. Bussines entrepreneur: Bussines entrepreneur adalah orang-orang terjun dalam dunia bisnis atau pelaku bisnis. Bussines entrepreneur dapat dibedakan ke dalam 2 kategori, yaitu: (a) Owner entrepreneur, yaitu para pecipta atau pemilik bisnis, dan (b) Professional entrepreneur, yaitu orang-orang yang memiliki daya wirausaha namun mempraktikkannya di perusahaan milik orang lain.

2. Goverment entrepreneur: Adalah Seorang atau kelompok orang yang memimpin serta mengelola lembaga negara atau instansi pemerintah dengan jiwa dan kecakapan wirausaha.

3. Social entrepreneur: Merupakan pendiri organisasi-organisasi sosial kelas dunia yang menghimpun dana masyarakat untuk sosial yang mereka yakini.

4. Academic entrepreneur: Merupakan akademisi yang mengajar atau mengelola lembaga pendiodikan dengan pola dan gaya enterpreneur sambil menjaga tujuan mulia pendidikan. ${ }^{11}$

Proses kewirausahaan diawali dengan adanya inovasi. Inovasi dipengaruhi secara internal dan eksternal. Inovasi yang dipengaruhi secara

${ }^{11 Z u l f i t r i a ~ d a n ~ Z a i n a l ~ A r i f, ~ " M e m b a n g u n ~ K e w i r a u s a h a a n ~(E n t r e p r e n e u r s h i p) ~ Q u r ' a n i ~ d i ~}$ Perguruan Tinggi", Rausyan Fiker Jurnal Pemikiran dan Penceraban, Vol. 14, No. 1, 2018, hlm. 143 154, Online, http://jurnal.umt.ac.id/index.php/RausyanFikr/article/view/684 
internal, yaitu: toleransi, nilai-nilai, pendidikan, dan pengalaman. Sedangkan faktor eksternal, yaitu: peran, aktivitas, dan peluang. Faktor internal dan eksternal ini mempengaruhi dalam membentuk karakter seseorang untuk berinovasi dalam kewirausahaan. Faktor-faktor tersebut berkontribusi dalam kreativitas, inovasi, implementasi, dan pertumbuhan untuk menjadi wirausaha yang besar. ${ }^{12}$

\section{Karakteristik Peserta Didik SD/MI}

Periode SD/MI dapat di bagi ke dalam dua periode, yaitu: pertama, kelas rendah SD/MI, yaitu umur 6 tahun sampai dengan 9 tahun. Kedua, kelas tinggi SD/MI yaitu umur 10 sampai dengan 13 tahun. Berdasarkan periode-periode tersebut tugas perkembangan peserta didik SD/MI, antara lain: Mengembangkan pemahaman-pemahaman yang diperlukan dalam kehidupan sehari-hari, Mengembangkan nilai, etika, dan moral, Mencapai kebebasan pribadi, Mengembangkan sikap-sikap sosial. ${ }^{13}$ Menurut Piaget, ada empat tahapan klasifikasi perkembangan kognitif anak, yaitu: Tahap sensorymotor, pada usia 0-2 tahun, tahap pre-operational, pada usia 2-7 tahun, tahap concrete-operational, pada usia 7-11 tahun, dan tahap formal-operational, yakni pada usia 11-15 tahun. ${ }^{14}$

Keterampilan yang akan dimiliki peserta didik SD/MI rentang usia 6-13 tahun. Keterampilan yang dicapai diantaranya, keterampilan sosial tolong-menolong (social belp skills)dan keterampilan bermain (play skill). Keterampilan social help skills yang berkembang dengan baik dapat bermanfaat dalam membantu orang lain. Keterampilan ini mendorong anak untuk mamou bekerjasama dengan orang lain. Dengan keterampilan ini menambah perasaan harga diri, menunjukkan keakuannya tentang jenis kelamin, kemandirian, sahabat, kemampuan berbagi dengan rekan sebaya. Sedangkan keterampilan play skill merupakan keterampilan dalam bermain yang memanfaatkan kemampuan motorik, seperti lari, lompat, lempar, emnagkap, keseimbangan, dan lainnya. ${ }^{15}$ Peserta didik usia SD/MI berada pada tahapan operasional konkret. Berdasarkan tahapan perkembangan berfikir tersebut, peserta didik sekolah dasar memiliki tiga ciri, yaitu: Konkret, Integratif, dan Hierarki. ${ }^{16}$

${ }^{12}$ Zulfitria dan Zainal Arif, Membangun Kewirausahaan (Entrepreneurship)..., hlm. 143-

${ }^{13}$ Novan Ardy Wiyani, Konsep, Praktik, \& Strategi Membumikan Pendidikan Karakter di SD/MI, Yogyakarta: Ar-Ruzz Media, 2013, hlm. 146-147

${ }^{14}$ Muhibbinsyah, Psikologi Pendekatan dengan Pendekatan Baru, Bandung: Remaja Rosdakarya, 2011, hlm. 66

${ }^{15}$ Novan Ardy Wiyani, Konsep, Praktik, \& Strategi..., hlm. 147-148

${ }^{16}$ Desmita, Psikologi Perkembangan Peserta Didike, Bandung: Remaja Rosda Karya, 2009, hlm. 104 
Pada tahap operasional konkret ini, peserta didik SD/MI tidak dapat berpikir baik secara logis maupun abstrak. Peserta didik SD/MI kemampuan berpikirnya terbatas pada berpikir konkret (nyata, pasti, tepat, uni-direksional) istilah yang lebih menunjukkan pengalaman nyata dan konkret ketimbang abstrak. ${ }^{17}$ Kelemahan cara berpikir operasional konkret ini adalah peserta didik mampu melakukan aktivitas logis (operasi) tetapi hanya dalam situasi yang konkret. Dengan kata lain. Bila peserta didik dihadapkan dengan suatu masalah secara verbal, yaitu tanpa adanya bahan yang konkret, maka peserta didik belum mampu untuk menyelesaikan masalah ini dengan baik. $^{18}$

\section{METODE PENELITIAN}

Penelitian ini bertujuan untuk membahas dan mengetahui implementasi pendidikan entrepreneurship di sekolah dasar/madrasah ibtidaiyah. Dalam penelitian ini, penulis menggunakan pendekatan kualitatif. Jenis data penelitian ini adalah data kualitatif dan sumber datanya berupa data skunder. Data skunder merupakan data-data yang telah ada pada obyek penelitian atau penelitianpenelitian terdahulu yang telah dilakukan yang bersumber dari berbagai dokumen yang dianggap relevan dengan masalah yang dibahas. Sedangkan metode pengumpulan data yang digunakan adalah penelitian kepustakaan (library research). Teknik analisis data dilakukan melalui reduksi data, display data, dan gambaran kesimpulan dari studi literatur/kepustakaan yang dilakukan. Sedangkan untuk pengecekan keabsahan data menggunakan triangulasi sumber data.

\section{HASIL DAN PEMBAHASAN}

Berdasarkan penelusuran kepustakaan dan data-data yang telah ada pada obyek penelitian atau penelitian-penelitian terdahulu yang telah dilakukan dapat dijelaskan, bahwa tahap-tahap implementasi pendidikan kewirausahaan (entrepreneurship) di sekolah dasar/madrasah ibtidaiyah adalah sebagai berikut.

\section{A. Tahap Perencanaan Pendidikan Entrepeneurship di SD/MI}

Pada tahap perencanaan guru memilih materi pelajaran kemudian memasukan nilai-nilai pendidikan entrepreneurship yang akan dikembangkan dalam RPP (Rencana Pelaksanaan Pembelajaran) materi pelajaran. Rencana Pelaksanaan Pembelajaran (RPP) meliputi: identitas mata pelajaran, Kompetensi Inti (KI), Kompetisi Dasar (KD), materi ajar, metode, alokasi

\footnotetext{
${ }^{17}$ Sudarwan Danim, Perkembangan Peserta Didik, Bandung: Alfabeta, 2011, hlm. 64

18F.J. Monks, dkk., Psikologi Perkembangan, Yogyakarta: Gadjah Mada University Press, 2006, hlm. 223
} 
waktu, kegiatan pembelajaran, penilaian pembelajaran, dan sumber belajar. ${ }^{19}$ Melalui kurikulum 2013, peserta didik diharapkan memiliki keseimbangan dalam sikap, pengetahuan dan keterampilan yang akan diterapkan dalam kehidupannya. Ketiga dimensi tersebut dikembangkan melalui Kompetensi Inti (KI) yang kemudian dirinci dalam Kompetensi (KD) dari masing-masing mata pelajaran. KD tersebut bekerja secara akumulatif yaitu menghimpun KD dari setiap matapelajaran, kemudian saling memperkuat dan memperkaya antar mata pelajaran dan antar jenjang pendidikan, sehingga tercapai pendidikan yang berkesinambungan dan bermakna. ${ }^{20}$

\section{B. Tahap Pelaksanaan Pendidikan Entrepreneurship di SD/MI}

Tahap pelaksanaan pendidikan entrepreneursip di sekolah dasar/madrasah ibtidaiyah dapat dilakukan melalui beberapa kegiatan, antara lain:

1. Kelas

Pelaksanaan pendidikan entrepreneurship disetiap kelas berbedabeda. Agar pelaksanaan pendidikan entrepreneurship dapat berjalan efektif dan efisien, maka dalam pelaksanaannya di dalam kelas dapat dibedakan ke dalam dua fase, yaitu: fase persiapan dan fase lanjutan atau aplikasi.

Fase persiapan dimulai dari kelas 1, 2, dan 3. Sedangkan fase lanjutan adalah fase yang merupakan fase dari kelas 4, 5, dan 6 .

2. Mata Pelajaran Entrepreneurship

Pemberian mata pelajaran entrepreneur dalam pembelajaran dapat dilakukan oleh sekolah dengan tetap memperhatikan sebaran mata pelajaran dan alokasi waktu sesuai dengan struktur kurikulum yang telah ditetapkan pemerintah. Sebagaimana hasil penelitian yang telah dilakukan oleh Afifah di satu Kota di Provinsi Jawa Timur, yaitu di Kabupaten Ponorogo. Diketahui bahwa baru ada satu yayasan pendidikan tingkat dasar yang menerapkan pendidikan entrepreneur, yaitu yayasan Qurrota A'yun Ponorogo. Di Madrasah Ibtidaiyah Terpadu Qurrota A'yun memiliki program unggulan yaitu pendidikan entrepreneur. ${ }^{21}$

${ }^{19}$ Hidayah dan Indri Delitasari, "Implementasi Pendidikan Entrepreneurship di SD Entrepreneur Muslim Alif-A Piyungan Yogyakarta", Proceeding The $6^{\text {th }}$ University Research Colloquium 2017: Seri Pendidikan,Universitas Muhammadiyah Magelang. 2017, hlm. 179-186. http://journal.ummgl.ac.id/index.php/urecol/article/view/1379

${ }^{20}$ Tika Meldina, Melinedri, Alfiana Agustin, dan Siti Hadijah Harahap, "Integrasi Pembelajaran IPS pada Kurikulum 2013 di Sekolah Dasar" AR-RIAYAH : Jurnal Pendidikan Dasar [Online], $\quad$ Volume 4 Number 1 (30 June 2020). http://journal.iaincurup.ac.id/index.php/JPD/article/view/1572

${ }^{21}$ Dian Nurul Afifah, Peran Pendidikan Entrepreneur dalam Membangun Kreativitas dan Kemandirian Siswa (Studi Kasus di Madrasab Ibtidaiyah Terpadu Qurrota A'yun Ponorogo), Skripsi, IAIN Ponorogo. 2019.http://etheses.iainponorogo.ac.id/7022/ 
3. Terintegrasi dengan Mata Pelajaran

Berdasarkan hasil penelitian Delitasari dan Hidayah yang dilakukan di Sekolah Dasar Entrepreneur Muslim Alif-A Yogyakarta, pendidikan entrepreneurship dapat diintegrasikan melalui mata pelajaran. Materi yang diintegrasikan pada pendidikan entrepreneurship dan bertujuan meningkatkan kreatifitas adalah SBK. Selain SBK, mata pelajaran yang diintegrasikan pada pendidikan entrepreneurship adalah Matematika, IPA, dan IPS. Pelaksanaan pengintegrasian peserta didik diarahkan untuk menciptakan sebuah karya yang dapat memiliki nilai jual. Kegiatan Pengembangan Diri

Pendidikan entrepreneurship di sekolah dapat diintegrasikan melalui pengembangan diri, seperti: market day, bussines day, entrepreneur zone, pesantren entrepreneur, outbond entrepreneur, kunjungan industri, dan cooking class. $^{22}$

4. Kultur Sekolah

Kultur sekolah adalah kumpulan nilai, norma, keyakinan, dan tradisi yang dipegang warga sekolah sebagai pengikat kebersamaan dan identitas sekolah. Bentuk kegiatan implementasi pendidikan entrepreneurship melalui kultur sekolah adalah peserta didik terbiasa secara mandiri melaksankaan sholat dhuha sendiri maumpun berjamaah, melaksanakan sholat zuhur di mushola sekitar sekolah, dan bertanggungjawab menata kursi untuk wali peserta didik. Melalui kegiatan tersebut, peserta didik ditanamkan untuk taqwa kepada Allah dan menyadari bahwa sholat dhuha merupakan kunci kesuksesan dunia dan akhirat. ${ }^{23}$

\section{Tahap Evaluasi Pendidikan Entrepreneurship di SD/MI}

Untuk mengukur keberhasilan peserta didik dalam proses pembelajaran pendidikan entrepreneurship dilakukan dengan melakukan evaluasi atau penialaian. Guru membuat catatan berdasarkan perkembangan peserta didik dalam melaksanakan pembelajaran entrepreneurship. Setelah dinilai, nilai pendidikan entrepreneurship di laporan hasil belajar peserta didik. Penilaian pendidikan entrepreneurship didasarkan pada nilai-nilai entrepreneurship yang telah terinternalisasi dan terimplementasi yang membentuk karakter dan perilaku yang terlihat pada aktivitas peserta didik di sekolah. ${ }^{24}$

Penerapan dari 17 nilai-nilai pokok kewirausahaan atau entrepreneurship tersebut dapat dilaksanakan secara bertahap tidak secara sekaligus oleh satuan pendidikan. Untuk di sekolah dasar, penerapan nilai-nilai pokok kewirausahaan atau entrepreneurship dapat dilakukan secara bertahap, misalnya

\footnotetext{
${ }^{22}$ Hidayah dan Indri Delitasari, "Implementasi Pendidikan Entrepreneurship...”, Op. Cit., hlm. 179-186

${ }^{23}$ Hidayah dan Indri Delitasari, "Implementasi..,hlm. 179-186

${ }^{24}$ Ibid.., hlm. 179-186
} 
penerapan nilai-nilai kewirausahaan diambil 6 (enam) nilai pokok yaitu mandiri, kreatif, berani mengambil risiko, berorientasi pada tindakan, kepemimpinan dan kerja keras. ${ }^{25}$

Penerapan tersebut tidak secara mutlak seluruh sekolah harus secara seragam menginternalisasi enam nilai-nilai kewirausahaan tersebut, namun setiap sekolah dapat menginternalisasikan nilai-nilai pokok kewirausahaan atau entrepreneurshipyang lain secara mandiri sesuai dengan kebutuhan sekolah. ${ }^{26}$

\section{KESIMPULAN}

Pendidikan edupreneurship sangat penting untuk diimplementasikan semenjak pendidikan di tingkat sekolah dasar/madrasah ibtidaiyah. Hal ini dilakukan untuk mempersiapkan generasi penerus di masa yang akan datang yang memiliki jiwa wirausaha yang selalu berkreasi dan berinovasi yang secara riil tercermin dalam kemampuan dan kemauan untuk memulai usaha (star up), mengerjakan sesuatu yang baru (creative), dan mencari peluang (opportunity).

Implementasi Pendidikan Entrepreneurship di sekolah dasar/madrasah ibtidaiyah dilaksanakan melalui beberapa tahap, yaitu: (1) Tahap perencanaan, meliputi: perumusan tujuan program, visi dan misi program pendidikan entrepreneurship, memilih materi pelajaran kemudian memasukan nilai-nilai pendidikan entrepreneurship yang akan dikembangkan dalam RPP (Rencana Pelaksanaan Pembelajaran); (2) Tahap pelaksanaan, meliputi: kelas, mata pelajaran entrepreneurship, teritegrasi dengan mata pelajaran, kegiatan pengembangan diri, kultur sekolah; dan (3) Tahap evaluasi, meliputi kegiatan penilaian pendidikan entrepreneurship yang didasarkan pada nilai-nilai entrepreneurship yang telah terinternalisasi dan terimplementasi yang membentuk karakter dan perilaku yang terlihat pada aktivitas peserta didik di sekolah.

\section{DAFTAR PUSTAKA}

Afifah, D. N. (2019) Peran Pendidikan Entrepreneur dalam Membangun Kreativitas dan Kemandirian Siswa (Studi Kasus di Madrasah Ibtidaiyah Terpadu Qurrota A'yun Ponorogo), Skripsi

Badan Pusat Statistik. (2020). [REVISI per 18/02/2021] Tingkat Pengangguran Terbuka (TPT) sebesar 7,07 persen

Danim, S. (2011). Perkembangan Peserta Didik. Bandung. Alfabeta.

Darwis, M. (2016). Pendidikan Entrepreneurship dalam Pespektif Global. TARBIYATUNA

\footnotetext{
${ }^{25}$ Tim Penulis Naskah Kewirausahaan, Pengembangan Pendidikan Kewirausahaan..., hlm. 11

${ }^{26}$ Tim Penulis Naskah Kewirausahaan, Pengembangan Pendidikan Kewirausahaan..., hlm. 11
} 
Desmita. (2009). Psikologi Perkembangan Peserta Didik. Bandung. Remaja Rosda Karya.

Ekawati, A. (2018). Market Day sebagai Upaya Pembiasaan untuk. Menumbubkah Jiwa Wirausaha Siswa Sejak Dini di SD IT Alam Harum Purbalingga. Skripsi. Universitas Muhammadiyah Purwokerto.

Fikriyati, M. (2013). Perkembangan Anak Usia Amas (Golden Age). Yogyakarta. Laras Media Prima.

Hidayah \&Delitasari, I. (2017). Implementasi Pendidikan Entrepreneurship di SD Entrepreneur Muslim Alif-A Piyungan Yogyakarta. Proceeding The $6^{\text {th }}$ University Research Colloquium 2017: Seri Pendidikan, Universitas Muhammadiyah Magelang.

Indiyani, S. \& Hartono, B. (2020). Analisis Pengangguran dan Pertumbuhan Ekonomi sebagai Akibat Pandemi Covid-19, Perspektif: Jurnal Ekonomi \& Manajemen Universitas Bina Sarana Informatika.

Izzaty, R. E. dkk. (2008). Perkembangan Peserta Didik. Yogyakarta. UNY Press.

Kholifah, N. \& Nurtanto, M. (2016). Pengembangan Pendidikan Kewirausahaan Dalam Menanamkan Nilai-Nilai Entrepreneurship Untuk Menghadapi Masyarakat Ekonomi ASEAN (MEA). Prosiding Seminar Nasional Inovasi Pendidikan: Inovasi Pembelajaran Berbasis Karakter dalam Menghadapi Masyarakat Ekonomi ASEAN.

Meldina, T., Melinedri, M., Agustin, A., \& Harahap, S. (2020). Integrasi Pembelajaran IPS pada Kurikulum 2013 di Sekolah Dasar. AR-RLAYAH : Jurnal Pendidikan Dasar,

Midayanti. N. (2018). Keadaan Ketenagakerjaan Indonesia Februari 2018. Jakarta. Badan Pusat Statistik.

Monks, F.J. dkk. (2006). Psikologi Perkembangan. Yogyakarta. Gadjah Mada University Press.

Muchson. (2017). Buku Ajar Entrepreneurship (Kewirausahaan). Jakarta. Guepedia.

Muhibbinsyah. (2011). Psikologi Pendekatan dengan Pendekatan Baru. Bandung. Remaja Rosdakarya.

Nurbudiyani, I. (2015). Manajemen Pengembangan Kewirausahaan (Entrepreneurship) Siswa SMKN-2 Palangkaraya. Pedagogik: Jurnal Pendidikan.

Peraturan Menteri Pendidikan dan Kebudayaan Republik Indonesia Nomor 20 Tahun 2016 Tentang Standar Kompetensi Lulusan Pendidikan Dasar dan Menengah

Soegoto, E. S. (2009). Entrepreneurship Menjadi Pebisnis Ulung. Jakarta. PT Gramedia.

Subroto, W. (2015). Menanamkan Nilai-Nilai Entrepreneurship Melalui Pendidikan Ekonomi Pada Era Masyarakat Ekonomi ASEAN. Jurnal Economia, 
Tim Penulis Naskah Kewirausahaan. (2011). Pengembangan Pendidikan Kewirausahaan. Jakarta. Kementerian Pendidikan Nasional Badan Penelitian dan Pengembangan Pusat Kurikulum.

Wijatno, S.(2009). Pengantar Entrepreneurship. Jakarta. PT Gramedia Widiasarana Indonesia.

Wijatno, S. (2012). Entrepreneurship untuk Sekolah Dasar. Jakarta. Slemba Empat.

Wiyani, N. A. (2013). Konsep. Praktik. \& Strategi Membumikan Pendidikan Karakter di SD/MI. Yogyakarta. Ar-Ruzz Media.

Zulaiha, S. (2017). Pendekatan Metodologis Dan Teologis Bagi Pengembangan dan Peningkatan Kualitas Guru MI. AR-RIAYAH : Jurnal Pendidikan Dasar

Zulfitria \& Arif, Z. (2018). Membangun Kewirausahaan (Entrepreneurship) Qur'ani di Perguruan Tinggi. Rausyan Fiker Jurnal Pemikiran dan Pencerahan. 